\title{
PROFESIONALISME SEKRETARIS \\ BERORIENTASI GLOBAL
}

\author{
Qleh: Osurondi
}

(suwandi_59@yahoo.com)

\begin{abstract}
ABSTRAK
Profesi sekretaris sudah dikenal dalam dunia usaha disetiap perkantoran sekretaris sangat dibutuhkan untuk menangani arsip, urusan skeduling, surat menyurat, urusan administrasi kantor sampai urusan pribadi pimpinan. Sekretaris haruslah profesional dimana mereka mampu berperan sebagai asisten bagian administrasi, sekretaris eksekutif ataupun manajer kantor karena mereka memiliki keterampilan yang prima dan juga berorientasi global daripada fokus pada tugas kerja rutin yang telah ditetapkan. Selain memiliki keterampilan dasar yang sempurna (skill) para pimpinan menginginkan sekretarisnya mempunyai attitude yang baik pula, memiliki pengetahuan yang luas dan kreatif serta memiliki pemahaman yang tepat akan pekerjaannya. Pentingnya peran sekretaris di setiap perusahaan membuat seorang sekretaris harus terus meningkatkan kemampuannya untuk tetap bisa berperan terus menjadi tangan kanan pimpinan, Public Relations dan segala aspek yang berkenaan dengan tugasnya dalam membantu pimpinannya menjalankan roda perusahaan agar perusahaan tetap bisa berjalan dengan baik di dunia bisnis yang semakin sengit persaingannya.
\end{abstract}

\section{Pendahuluan}

Dada era ekonomi global dengan tingkat teknologi tinggi, para manajer butuh dukungan

yang besar dari para bawahannya untuk mengontrol sistem yang baru. Para pemimpin perusahaan dituntut untuk melengkapi diri dengan sederet kemampuan untuk berpacu dengan percepatan perubahan dalam dunia bisnis, sebagai penyeimbang terhadap berbagai kemudahan yang disediakan oleh kemajuan teknologi. Sedangkan kondisi dari para pengusaha pada saat ini mereka harus menghadapi berbagai tantangan dan persaingan yang ketat dalam dunia bisnis. Kondisi demikian membuat para pimpinan perusahaan membutuhkan jasa sekretaris yang lebih handal dan profesional. Era globalisasi informasi yang diwarnai dengan kemajuan teknologi informasi dimana hal ini berpengaruh terhadap orang-orang yang menggeluti profesi sebagai sekretaris, pengaruh dari era ini sangat besar terhadap peran dan fungsi sekretaris dimana mereka harus menyesuaikan diri dan memperluas wawasan. fungsi dan peranan sekretaris semakin dibutuhkan oleh para manajer. Para manajer dalam memanfaatkan waktunya lebih berkonsentrasi pada tugas managerialnya yang penuh tantangan itu dan segala pekerjaan staf didelegasikan kepada sekretarisnya. 
Sebagai konsekuensi logis sekretaris pun akan menghadapi tantangan yang berat. Peran-peran sekretaris konvensional yang bersifat administratif dan klerikal sebagian besar telah tergantikan oleh perangkat teknologi informasi. Oleh karena itu tingkat kompetensi sekretaris menjadi mutlak untuk ditingkatkan sebagai pendukung kinerja para pimpinan perusahaan.

\section{DEFINISI SEKRETARIS}

Istilah sekretaris berasal dari bahasa latin yaitu secretum yang artinya rahasia. Dalam Bahasa Belanda yaitu secretares, dalam Bahasa Perancis disebut secretaire, sedangkan dalam Bahasa Inggris disebut secretary yang berasal dari kata secret yang berarti rahasia. Sesuai dengan asalnya, Berarti Sekretaris adalah orang yang diberi kepercayaan untuk menyimpan rahasia dalam melaksanakan pekerjaannya dalam arti rahasia perusahaan atau yang tidak perlu diketahui oleh orang lain atau para pegawai.

Pengertian sekretaris dari Wikipedia bahasa Indonesia, ensiklopedia bebas menyatakan bahwa :

Sekretaris adalah sebuah profesi administratif yang bersifat asisten atau mendukung. Gelar ini merujuk kepada sebuah pekerja kantor yang tugasnya ialah melaksanakan perkerjaan rutin, tugas-tugas administratif atau tugas-tugas pribadi dari atasannya. Pekerja atau karyawan ini biasanya melakukan tugas-tugas seperti mengetik, penggunaan komputer dan pengaturan agenda. Mereka biasanya bekerja di belakang meja. Sebagian besar sekretaris adalah wanita http://id.wikipedia.org. Sekretaris menurut H. W Fowler dan F. G Fowler yang dikutip oleh Nani Nuraeni dalam buku Sekretaris Professional mengemukakan bahwa Sekretaris adalah orang yang bekerja pada orang lain untuk membantu dalam korespondensi, pekerjaan tulis, mendapatkan informasi dan masalah-masalah lainnya; Pegawai yang ditunjuk oleh masyarakat atau perusahaan atau perserikatan untuk melakukan korespondensi, memelihara warkat-warkat, terutama yang berurusan dengan perusahaannya.; Menteri yang mengepalai kantor pemerintahan, menteri di Amerika Serikat dan Vatikan.(2008:2)

Menurut C. L Barnhart, yang dikutip oleh Nani Nuraeni dalam buku Sekretaris Professional menyatakan bahwa :

ekretaris adalah seorang yang melakukan korespondensi, memeli hara warkat dan
lainnya untuk perorangan atau organisasi; Seorang kepala pejabat pemerintah yang 
mengawasi dan memimpin suatu departemen pemerintahan tertentu; .Sebuah meja dan rak buku diatasnya. .(2008:2) yang dimaksud warkat sendiri menurut The Liang Gie yang dikutip oleh Nani Nuraeni dalam buku Sekretaris Professional menyatakan warkat adalah setiap catatan tertulis, bergambar atau terekam yang berisi keterangan tentang suatu peristiwa atau hal yang dibuat orang untuk membantu ingatan (contohnya buku, surat, arsip, dan kuitansi) .(2008:2)

Pengertian sekretaris Menurut Louis C. Nahassy dan William Selden seperti yang dikutip oleh Sutarto dalam buku Sekretaris dan tatawarkat menyatakan

"Secretary is an office employee who has a more responsible position than a stenographer and whose duties usually include taking and transcribing dictation; dealing with the public by answering the telephone, meeting callers, and making appointment ; and maintaining or filing records, letters, etc, A secretary frequently acts as an administrative assistant or Junior executive”.

Sekretaris adalah:"Seorang pegawai kantor yang memiliki kedudukan yang lebih bertanggung jawab daripada seorang stenographer dan tugas-tugasnya biasanya meliputi pengambilan dan penyalinan dikte berurusan dengan publik untuk menjawab telepon, mengundang pertemuan, membuat perjanjian dan memelihara atau mengarsip warkat-warkat, surat-surat, dan lain-lain. Seorang sekretaris sering bertindak sebagai seorang pembantu administrasi atau pimpinan muda." (1997:4).

Beberapa definisi lain mengenai sekretaris :

Pengertian Sekretaris Menurut Betty Hutchinson dan Carol Milano yang dikutip oleh Ursulla Ernawati dalm buku Pedoman lengkap Kesekretarisan mengemukakan a secretary is a professional as a professional you may want to perform the many and varied responsibilities of secretarial work with competence, confidence, and style

Seorang Sekretaris adalah seorang professional, sebagai seorang professional sekretaris diharapkan menampilkan aneka macam tanggung jawab tugas kesekretarisan dengan penuh kompetensi, dapat dipercaya dan berkepribadian (2004:1)

Professional Secretaries International (PSI) :

" A secretary shall be defined as an executive assistant who possesses a mastery of office skills, demonstrates the ability to assume responsibility without direction or supervision 
exercises initiative and judgement and makes decisions within the scope of assigned authority"

Seorang sekretaris adalah assisten pimpinan yang memiliki keahlian mengurus kantor, menampilkan kemam puan menerima tanggung jawab tanpa diarahkan atau diawasi, berinisiatif dan penuh pertimbangan, serta mengambil keputusan sesuai dengan ruang lingkup wewenang tugasnya. (2004:2)

Berdasarkan uraian diatas mengenai sekretaris, maka secara umum sekretaris adalah seorang karyawan atau pegawai yang diangkat oleh pimpinannya sebagai pembantu pribadinya tetapi tidak hanya sekedar pembantu pimpinan saja ia juga dapat mengerjakan tugas-tugas, pekerjaan kantor, memegang rahasia perusahaan dan tanggung jawab yang tinggi di kantor atau perusahaan, karena dianggap dapat dipercaya dalam mengerjakan tugastugas pimpinan, dimana pimpinan tersebut memiliki tugas dan tanggung jawab yang besar dalam memimpin dan mengelola organisasi atau perusahaan dari mengurus perjanjian , administrasi, mengatur rapat hingga korespondensi. Semua tugas pimpinan tersebut akan menjadi maksimal jika ada seorang sekretaris yang mendampinginya

\section{MACAM-MACAM SEKRETARIS BERDASARKAN RUANG LINGKUP DAN TANGGUNG JAWAB}

Berdasarkan ruang lingkup dan tanggung jawab sekretaris dapat dibedakan menjadi 2 (dua) macam yaitu:

\section{Sekretaris eksekutif}

Sekretaris eksekutif adalah sekretaris yang juga berfungsi sebagai manajer karena secara langsung atau nyata menjalankan fungsi manajer eksekutif yang memiliki bawahan. Sekretaris eksekutif ini pada umumnya merupakan sekretaris untuk satu unit organisasi, contohnya: sekretaris dewan, sekretaris jenderal, sekretaris wilayah, sekretaris inspektorat jenderal, sekretaris yayasan, dan lain-lain.

\section{Sekretaris pribadi}

Sekretaris pribadi adalah seorang yang mengerjakan kegiatan perkantoran untuk membantu seseorang tertentu dan bersifat pribadi. Sekretaris dalam pengertian ini bukan pegawai atau staf dari suatu organisasi atau perusahaan tetapi diangkat dan digaji oleh perorangan. Seorang sekretaris pribadi harus selalu berusaha untuk mengenal sifat-sifat dan pribadi pimpinannya sendiri, baik itu adat kebiasaan, kegemaran atau hobi, kelebihan dan kekurangan pimpinan. Sebagai sekretaris pribadi tidak berarti bahwa ia tidak 
bertanggung jawab kepada unit kerjanya, tetapi ia tetap terikat kepada status kepegawaiannya.

\section{MACAM-MACAM SEKRETARIS BERDASARKAN KEMAMPUAN DAN PENGALAMAN KERJA}

Berdasarkan kemampuan dan pengalaman kerjanya macam sekretaris dapat dibedakan menjadi 2 (dua) macam yaitu:

\section{Sekretaris senior}

Sekretaris senior adalah sekretaris yang sudah memiliki banyak pengalaman yang mantap, dapat berdiri sendiri dalam mengatasi masalah yang timbul di dalam pelaksanaan tugasnya.

\section{Sekretaris junior}

Sekretaris junior adalah sekretaris yang baru memulai kariernya atau baru bekerja dan belum mempunyai banyak pengalaman karena ia baru keluar dari pendidikan sekretaris. Sekretaris junior ini perlu banyak belajar dan bimbingan dari seorang sekretaris senior untuk memperoleh tambahan ilmu dan pengalaman.

\section{TUGAS SEKRETARIS}

Tugas seorang sekretaris adalah membantu pimpinan dalam melaksanakan pekerjaan-pekerjaan teknis, tetapi cukup penting artinya bagi pimpinan. Seorang pimpinan akan sangat memerlukan bantuan sekretaris dalam melaksanakan pekerjaan-pekerjaan kantor seperti :

1. Menerima tamu

2. Menerima telepon

3. Mengambil dikte dan melatinkan

4. Menyimpan surat

Untuk itu seorang pemimpin meng harapkan bahwa bantuan yang diberikan oleh seorang sekretaris akan berbeda tergantung dari bidang usaha yang diberikan oleh pimpinan misalnya direktur dari perusahaan percetakan akan berbeda dengan lembaga bantuan hukum. Seorang sekretaris harus selalu berusaha untuk mencari cara-cara yang baik untuk menumbuhkan hubungan dan kerja sama yang baik antara sekretaris dengan pimpinannya dalam batas-batas kedinasan. 
Pada dasarnya tugas-tugas sekretaris meliputi :

\section{Tugas-tugas Rutin}

Yaitu tugas-tugas umum yang dikerjakan oleh sekretaris setiap harinya tanpa menunggu instruksi dari pimpinan atau tanpa menunggu waktu sudah harus dilaksanakan sesuai dengan yang telah diterapkan. Tugas ini meliputi:
a. Membuka surat.masuk untuk pimpinan
b. Menerima dikte.
c. Menerima dan melayani tamu serta bertamu mewakili pimpinan.
d. Menerima dan melayani telepon serta menelpon.
e. Menata arsip/surat.
f. Menyusun dan membuat surat untuk kepentingan pimpinan (korespondensi)
g. Mengurus dan mengendalikan surat
h. Menyiapkan pembuatan laporan
i. Menyusun dan membuat jadwal kegiatan pimpinan.
j. Mengelola kas kecil
k. Menjaga kebersihan dan kerapihan kantor untuk menciptakan kenyamanan kerja

\section{Tugas-tugas khusus}

Tugas-tugas ini tidak selalu setiap hari dilaksanakan oleh sekretaris tetapi hanya dilaksanakan bila diperintahkan langsung/ instruksi khusus oleh pimpinan kepada sekretaris dengan penyelesaiannya secara khusus. Jadi yang dimaksud tugas disini adalah pekerjaan yang hanya kadang-kadang dihadapi akan tetapi harus dilaksanakan sebaikbaiknya dan adanya unsur kepercayaan bahwa tugas sekretaris mampu menyimpan rahasia perusahaan.juga pimpinan beranggapan bahwa untuk tugas tertentu sekretaris dianggap sudah menguasai sehingga pimpinan memberikan kepercayaan kepada sekeretaris untuk menyelesaikan tugas tersebut Tugas ini meliputi:
a. Menyiapkan rapat dan membuat notulen
b. Mengonsep surat perjanjian kerjasama dengan relasi atau instansi luar.
c. Menyusun surat rahasia (confidential).
d. Menyiapkan perjalanan dinas pimpinan ( pemesanan tiket, booking hotel, menyusun agenda perjalanan pimpinan sampai mencatat pengeluaran biaya perjalanan dinas )
e. Menyusun acara pertemuan bisnis.
f. Menyusun makalah, pidato untuk pimpinan 
g. Mengurus masalah dengan bank

h. Mendatangi perusahaan lain atau instansi pemerintahuntuk mencari informasi atau menyampaikan informasi

i. Pembelian kado atau cindera matauntuk klien pada even-even tertentu.

\section{Tugas-tugas istimewa}

Yaitu tugas yang menyangkut keperluan pimpinan, antara lain:

a. Membetulkan letak atau posisi alat tulis pimpinan serta perlengkapan yang diperlukan.

b. Bertindak sebagai penghubung untuk meneruskan informasi kepada relasi.

c. Mewakili seseorang menerima sumbangan untuk dana atau keperluan kegiatan lainnya.

d. Mengingatkan pimpinan membayar iuran atau asuransi dari suatu badan atau instansi.

e. Memeriksa hasil pengumpulan dana atau uang muka dari instansi yang diberikan sebagai dana kesejahteraan.

f. Menghadiri rapat-rapat dinas, sebagai pendamping pimpinan selama mengadakan pertemuan bisnis.

g. Mengadakan pemeriksaan peralatan kantor, mana yang perlu diperbaiki dan mana yang tidak perlu diperbaiki atau penambahan alat-alat dan sarana kantor.

\section{Tugas Sosial}

Tugas sosial, meliputi:

a. Mengurusi Rumah tangga kantor.

b. Mengatur penyelenggaraan resepsi untuk kantor pimpinan beserta pengurusan undangannya.

c. Menyampaikan ucapan selamat atau menyatakan bela sungkawa kepada relasi atas nama pimpinan

\section{Tugas Keuangan}

Biasanya sekretaris mengurusi keuangan yang dinamakan petty cash (uang cadangan/kas kecil). Tugas keuangan ini antara lain:

a. Menangani urusan keuangan pimpinan di Bank, misalnya: penyampaian penyimpanan uang di Bank, penarikan cek, pengambilan uang dari Bank.

b. Membayar rekening-rekening, pajak, sumbangan dana atas nama pimpinan. 
c. Menyimpan catatan pengeluaran sehari-hari untuk pimpinan dan penyediaan dana untuk keperluan sehari-hari.

\section{Tugas Resepsionis}

Tugas sekretaris sebagai resepsionis, yaitu:

a. Menerima dan menjawab telepon serta mencatat pesan-pesan lewat telepon.

b. Menerima tamu yang akan bertemu dengan pimpinan.

c. Mencatat janji-janji untuk pimpinan

d. Menyusun acara kerja sehari-hari pimpinan.

\section{Tugas insidental}

Tugas ini merupakan pekerjaan yang tidak rutin dilakukan oleh sekretaris meliputi:

a. Menyiapkan agenda rapat, menyiapkan laporan, menyiapkan pidato atau pernyataan pimpinan.

b. Membuat ikhtisar dari berita-berita dan karangan yang termuat dalam surat kabar, majalah, brosur, dan media-media lain yang ada kaitannya dengan kepentingan perusahaan.

c. Mengoreksi bahan-bahan cetakan, misal: brosur, undangan, formulir, dan daftar yang dikonsep oleh perusahaan.

d. Mewakili pimpinan dalam berbagai resepsi atau pertemuan.

\section{Tugas sekretaris dalam Business Meeting (pertemuan bisnis)}

Pertemuan bisnis (Business Meeting) ini terjadi ketika dua orang atau lebih saling menerima dan memberi sesuatu berupa informasi, menyimak kembali kemajuan, memecahkan masalah dan menciptakan yang baru. Tugas inilah yang cukup berat dan melelahkan bagi sekretaris untuk mengorganisir perte muan-pertemuan tersebut.

\section{Tugas kreatif}

Tugas atas prakarsa sendiri sendiri yakni tanpa diminta oleh pimpinan, tugas ini hasil pertimbangan sekretaris tentang perlu tidaknya sesuatu dikerjakan sehingga dapt membantu, meringankan beban pekerjaan pimpinan tugas kreatif meliputi
a. Membuat perencanaan kerja
b. Mempelajari pengetahuan tentang bank
c. Mempelajari pengetahuan tentang kas kecil
d. Pemantapan kepribadian
e. Efisinsi kerja 
f. Pengembangan diri sekretaris dengan mengikuti seminar, pelatihan ataupun kursus yang menunjang pekerjaan

g. Mengirmkan bunga atau surat ucapan selamat kepada rekan pimpinan yang memperoleh promosi jabatan

h. Menyiapkan perabot kantor perlengkapan dan alat-alat penting bagi sekretaris

i. Membuat kliping iklan atau artikel yang dibutuhkan perusahaan

j. Mengumpulkan brosur, pricelist dari berbagai macam pameran yang berguna bagi perusahaan

k. Memahami cara kerja mesin kantor dan audio visual ( alat bantu peraga)

1. Memahami dan mempelajari organisasi, peraturan/ keadaan organisasi, product knowledge, budaya perusahaan tempat bekerja

\section{TANGGUNG JAWAB SEKRETARIS}

Selain sekretaris bertanggung jawab atas pekerjaannya ada tanggung jawab lain yang harus dilaksanakan yaitu:

1. Personal Responsibility (Tanggung Jawab Individu)

Sekretaris bertanggung jawab terhadap performansi diri sendiri dan upaya pengembangan ke arah yang lebih berkualitas. Dengan "mengelola" diri sendiri supaya dapat tampil dengan performansi prima dalam pelaksanaan tugas pokok sehari-hari, antara lain:

a. Mempermudah dan memperlancar kerja pimpinan melalui pengaturan waktu dan distribusi informasi yang efisien.

b. Mendistribusikan informasi dari kantor pimpinan secara jelas dan akurat.

c. Mendukung kelancaran alur kerja antara kantor pimpinan dengan bagian lainnya.

d. Memberikan peluang kepada pimpinan untuk lebih berfokus pada hal-hal strategis dan memiliki dampak jangka panjang.

e. Memberikan masukan positif dan inisiatif untuk perbaikan perusahaan.

\section{Internal Responsibility (Tanggung Jawab Dalam)}

Sekretaris bertanggung jawab terhadap upaya pencapaian superioritas kinerja kantor dan pengaruhnya terhadap kinerja perusahaan. Tanggung jawab ini terwujud melalui aktivitas:
a. Mengelola sumber daya kantor termasuk keuangan.
b. Menciptakan suasana (fisik dan mental) yang mendukung kelancaran kerja.
c. Mendukung penciptaan budaya kerja yang positif.
d. Membantu menciptakan "kelompok informal positif" di lingkungan perusahaan.
e. Mengelola anak buah untuk meningkatkan efektifitas dan efisiensi kerja di kantor. 


\section{Networking Responsibility (Tanggung Jawab Cabang Perusahaan)}

Tanggung jawab sekretaris untuk meluaskan wawasan dan jalinan perusahaan dengan tujuan peningkatan daya saing. Perwujudannya adalah melalui upaya memperluas network perusahaan, mengatur dan mengawasi pelaksanaan acara-acara formal dan informal yang diselenggarakan oleh kantor dalam kaitannya dengan upaya mempertahankan dan berpartisipasi dalam mengembangkan citra perusahaan.

4. Tanggung jawab atas keberhasilan perusahaan .

Dalam peran aktifnya membantu kelancaran tugas-tugas pimpinan sehingga dapat tercapai tujuan yang telah ditetapkan.

5. Tanggung jawab hukum seorang sekretaris.

Salah satu segi penting dari jabatan sekretaris, walaupun kemungkinan besar tidak tercantum dalam peraturan tertulis, adalah tanggung jawab hukumnya sebagai perantara pimpinan dalam transaksi. Sebagai perantara, berarti sekretaris berperan menjadi wakil pimpinan dalam urusan bisnis dengan pihak ketiga, karena sekretaris mem punyai wewenang ini. Jadi sekretaris harus bertindak hati-hati dan bertanggung jawab.

\section{FUNGSI}

Sekretaris dibutuhkan oleh setiap pimpinan untuk meringankan tugas pimpinan terutama tugas rutin dan operasional agar pimpinan dapat berkonsentrasi dan fokus terhadap tugas manjerialnya, pada dasarnya fungsi sekretaris adalah

1. Membantu meringankan tugas-tugas pimpinan juga sebagai alat pelaksana pusat ketatausahaan.

2. Mengadakan pencatatan dari semua kegiatan manajemen, sebagai pusat dokumentasi dan menangani informasi untuk pimpinan

3. Sebagai alat komunikasi organisasi / perusahaan menjadi jembatan penghubung

\section{PERANAN SEKRETARIS}

Pada dasarnya setiap sekretaris mempunyai peranan yang sama, yaitu membantu kelancaran pelaksanaan tugas-tugas pimpinan. Dalam melaksanakan tugas tersebut, seorang sekretaris 
bukan hanya berhubungan dengan pimpinannya saja melainkan juga dengan klien perusahaan, karyawan lain, juga dengan pekerjaan yang ditekuninya. Adapun peranan sekretaris adalah sebagai berikut

\section{Sekretaris sebagai duta.}

Peranan sekretaris dikatakan sebagai duta yaitu sekretaris sebagai wakil dari perusahaan sehingga penampilan dan sikapnya haruslah baik dan profesional, karena sekretaris bukan hanya berhubungan dengan masyarakat tersebut.

\section{Sekretaris sebagai pintu gerbang}

Peranan sekretaris dikatakan sebagai pintu gerbang karena fungsi sekretaris salah satunya adalah sebagai penerima tamu, untuk itulah letak meja dan kursi sekretaris berdekatan dengan pintu masuk ruangan pimpinan dimana para tamu, relasi, maupun karyawan sendiri yang ingin bertemu dengan pimpinan haruslah melapor atau ijin kepada sekretaris terlebih dahulu.

\section{Sekretaris sebagai ibu rumah tangga perusahaan.}

Di sini sekretaris harus dapat berperilaku selayaknya ibu dari perusahaan. Ia harus dapat menaungi perusahaan dan menjadi contoh yang baik dalam mengurus kantornya. Misalnya; membuat ruangan menjadi seperti rumah sendiri sehingga terasa nyaman agar para tamu, relasi, karyawan dan pimpinan di perusahaan merasa betah.

\section{Sekretaris sebagai humas.}

Sekretaris sebagai penghubung antara perusahaan dengan lingkungan kerja, lingkungan masyarakat, baik bertatap muka secara langsung melalui telepon, atau media yang lain. Dalam peranannya sebagai humas, sekretaris haruslah mengerti bagaimana menghadapi setiap orang yang tidak sama sifat dan perilakunya. Dalam menghadapi pihak lain, ia harus dapat menempatkan diri sesuai dengan situasi dan kondisi yang ada, demi tercapainya tujuan perusahaan apalagi bila perusahaan membutuhkan suatu kerjasama yang baik dengan seseorang atau lembaga lain.

\section{SEKRETARIS PROFESIONAL}

Sekretaris perlu mengembangkan diri melalui peningkatan kompetensinya sehingga benar-benar mampu dan berkualitas tinggi dalam membantu pimpinannya. Sebaiknya 
sekretaris melengkapi diri dengan berbagai pengetahuan dan keterampilan di luar tugas-tugas kesekretarisan yaitu :
a. Keterampilan berkomunikasi
b. Kemampuan mencari, menginterprestasikan dan memanfaatkan informasi
c. Mampu berpikir, mengidentifikasi masalah dan mencari solusinya
d. Mampu bekerja sama dalam kelompok
e. Memiliki Human Relation skills
f. Mempunyai komitmen pada tugas
g. Senantiasa bersemangat mengembangkan diri

Pada saat ini peran sekretaris profesional memang menjadi pertanyaan? dan tanggung jawab sekretaris profesional juga mendapat sorotan yaitu ketika posisi sekretaris akan segera tamat riwayatnya, tergilas oleh perkembangan office automation dan teknologi informasi. Berbagai perangkat teknologi informasi, telah menjadi alat bantu yang efektif bagi para manajer untuk menjadi sekretaris profesional bagi dirinya sendiri. pendapat ini berasumsi bahwa tugas sekretaris berkisar kepada tugas-tugas administratif, klerikal, dan resepsionis. Padahal, tugastugas sekretaris telah mengalami evolusi sesuai dengan tuntutan keadaan, posisi sekretaris justru mengalami job enlargement dan job enrichment. Seorang sekretaris profesional dapat dijadikan "Pusat Informasi" di dalam kantor, paling tidak sekretaris harus sangat mengetahui bagian yang ditanganinya sendiri. Dengan bertindak sebagai pusat informasi, sekretaris mampu menjalankan peran Strategis, Peran teknis dan peran pendukung.

$\mathrm{P}$ eran strategis yaitu peran yang diharapkan dapat memberikan pengaruh positif pada status dan performansi organisasi secara jangka panjang, yang tercapai melalui kelancaran arus informasi baik ke dalam maupun ke luar. Sedangkan peran teknis, yaitu peran yang diharapkan dapat meningkatkan kinerja pimpinan. Aktivitas seketaris sekretaris profesional yang menyalurkan informasi kepada pimpinan secara jelas dan akurat akan sangat membantu dan memfasilitasi pimpinan untuk menjalankan fungsinya dengan baik. Dengan demikian semakin berat beban kerja pimpinan, maka tugas sekretaris pun akan semakin internsif. Peran pendukung yaitu peran yang diharapkan dapat memberikan positif kepada anggota organisasi lainnya, yang dapat dicapai dengan pendistribusian informasi (incoming dan outgoing). Secara keseluruhan kedudukannya sebagai pusat informasi, memungkinkan sekretaris profesional berperan lebih jauh lagi untuk mengatur kalender dan jadwal pekerjaan, mengelola dokumen dan sistem penyimpanannya, sebagai event organizer 
untuk pertemuan internal dan eksternal, mengelola kondisi dan kerapian kantor, membentuk atmosfir kantor serta bertindak sebagai travel arranger pimpinan.

Peran sekretaris profesional bisa menjadi kunci fungsi yang efisien dari perusahaan, khususnya dalam organisasi dengan staf bergaji kecil atau anggota staf yang tidak tetap. Berikut adalah beberapa kualitas, keterampilan, dan pengetahuan yang harus ditunjukkan oleh sekretaris profesional dalam menjalankan tugasnya

\section{Knowledge (Pengetahuan)}

Syarat pengetahuan ini dibedakan menjadi 2 (dua) yaitu:

a. General Knowledge (pengetahuan umum).

Seorang sekretaris harus memiliki pengetahuan yang luas yang dapat mengangkat nama dari perusahaan. Juga Memiliki kemampuan memadai terhadap segala sesuatu perubahan dan perkembangan yang terjadi, terutama yang berkaitan dengan aktivitas organisasi Misalnya:

1. Menguasai dan memahami Bahasa Indonesia dengan baik dan benar serta menguasai beberapa bahasa asing secara lisan maupun tertulis, serta memiliki pengetahuan ekstra.

2. Pengetahuan tentang misi, fungsi, tugas-tugas, serta struktur organisasi, serta susunan personil.

3. Pengetahuan tentang korespondensi dan tata kearsipan. Memiliki pengatahuan tentang tata naskah, kearsipan dan peralatan perkantoran

b. Special knowledge ( pengetahuan khusus.).

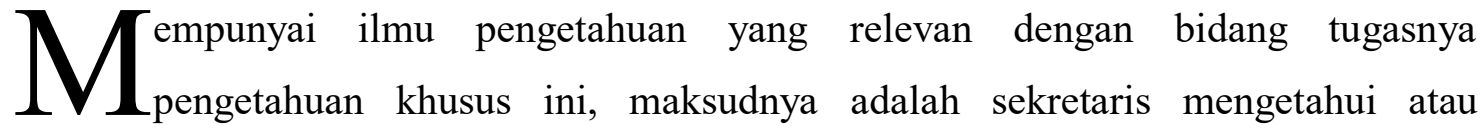
mengerti hal-hal mengenai dimana sekretaris itu bekerja. Apabila sekretaris itu bekerja pada perusahaan yang bergerak pada bidang usaha perkapalan, maka ia harus mampu menguasai ilmu perkapalan, begitu pula bila perusahaan itu bidang usahanya penyewaan apartemen, maka sekretaris itu harus menguasai ilmu keapartemenan, dan sebagainya. 


\section{Skill and technic (Keterampilan)}

Setiap sekretaris diharuskan memiliki keterampilan untuk menunjang pekerjaannya, keterampilan itu meliputi:
a. Mampu menyusun laporan
b. Mampu mengetik surat dan berkorespondensi
c. Mampu menggunakan bahasa indonesia dan bahasa asing
d. Manpu menggunakan teknologi perkantoran
e. Teknik tata penyimpanan arsip
f. Teknik berkomunikasi dengan telepon
g. Menulis cepat dengan steno
h. Senantiasa meng-upgrade keterampilan yang dimilikinya dengan perkembangan duniausaha/bisnis

\section{Personality.Kepribadian}

Tidak banyak orang mempunyai bakat untuk menjadi sekretaris yang baik, namun demikian bakat saja tidak cukup bilamana kita tidak tahu kepribadian yang bagaimana harus kita punyai untuk menjadi seorang sekretaris yang baik itu.

a. Memiliki kepribadian, penampilan diri yang menarik dan baik

b. Loyalitas disiplin dan dedikasi yang tinggi Dapat dipercaya serta memegang teguh rahasia

c. Ketekunan, ketelitian, kerapian, kejelian, kejujuran, memiliki ingatan yang baik keterbukaan, kesabaran, keramahtamahan serta tanggung jawabKualitas, keterampilan \& pengetahuan

d. Simpatik. Harus bersikap mawas diri dan pandai bergaul pandai berbicara, sopan

e. Mempunyai perhatian atas pekerjaannya tidak cepat menyerah

f. Dapat bijaksana terhadap orang lain bisa menjaga image perusahannya

\section{Practice}

Kemampuan melaksanakan tugas sehari-hari seperti menerima telepon, menerima tamu, menyiapkan rapat, membuat agenda pimpinan dll.

eorang sekretaris harus memiliki komitmen dan sikap yang dilandasi rasa tanggung
jawab pada tugas maka mereka akan menyelesaikan tugas atau pekerjaannya karena merasa terikat pada penyelesaian tugas tersebut, bukan karena terikat pada norma-norma formal, sehingga apabila tidak menyelesaikan tugas dengan sebaik-baiknya, mereka akan 
merasa bersalah dan bukannya takut pada sanksi. Namun apabila seseorang sekretaris terlalu sering menghindar diri dari tanggung jawab, sikap seperti ini mencerminkan kepribadian yang tidak dewasa, labil, tidak dapat dipegang.

Untuk itu sekretaris harus melatih diri untuk menjadi sekretaris yang penuh tanggung jawab, yang mampu bekerja mandiri, bekerja tanpa pengawasan, bahkan dituntut untuk mampu mengawasi dirinya sendiri.

\section{SEKRETARIS PROFESSIONAL YANG BERORIENTASI GLOBAL}

eorang sekretaris yang berorientasi global harus Menampilkan Citra perusahaan karena
Citra perusahaan adalah hal yang harus dijunjung tinggi. Dikarenakan sekretaris adalah tangan kanan atasannya, maka sekretaris juga harus menampilkan citra perusahaan yang baik. Selain itu seorang sekretaris harus ramah, baik dan bertanggung jawab pada semua tugasnya. Bukan hanya baik kepada atsannya saja tapi juga harus baik kepada relasi dan kawan sekantor. Sebagai tangan kanan dan selalu mendapat kepercayaan dari atasannya, Sekretaris harus pandai menjaga rahasia perusahaan maupun rahasia pribadi atasannya tersebut.

Sekretaris bukan hanya harus pandai berdandan, tapi seorang sekretaris juga harus up date terhadap kemajuan teknologi misalnya teknologi informasi. Accounting dan pembukuan juga harus dikuasai oleh seorang sekretaris agar bisa melakukan pembukuan kantor. Menguasai bahasa asing adalah nilai tambah yang harus dimiliki oleh seorang sekretaris. Karena biasanya sekretaris selalu diminta atasannya untuk bertemu dengan relasi yang berasal dari luar negeri. Seorang sekretaris setiap harinya berkomunikasi dengan tamu- tamu dengan berbagai tingkatan atau golongan. Untuk itu seorang sekretaris harus mampu berkomunikasi dengan baik dan menguasai bahasa Indonesia dan beberapa bahasa asing dengan baik. Ia pun dituntut untuk memilih kata dan menyususn kalimat secara baik dan jelas, menyenangkan semua pihak yang berkomunikasi dengannya. Untuk meningkatkan kualitas seorang pemimpin harus meningkatkan kualitas berkomunikasi dengan meningkatkan bahasa yang dimiliki seperti bahasa Inggris atau bahasa asing lainnya sehingga dapat berkomunikasi dengan tamu- tamu tingkat eksekutif, agar seorang sekretaris mampu membantu pimpinan dalam bernegosiasi. Adapun kriteria komunikasi yang efektif adalah sebagai berikut : 
a. Penerima mengerti atau memahami isi pesan

b. Penerima dapat menerima atau menyetujui isi pesan

c. Penerima mengadakan suatu tindakan (aksi), sesuai dengan yang dikehendaki oleh pengirim.

Dalam menghadapi atasannya seorang sekretaris yang profesional harus mempelajari karakter dari pimpinannya tidak salah dalam bertindak dan mengambil keputusan. Seorang sekretaris juga harus memiliki etika yang baik yaitu dalam hal berbicara, makan, duduk, dsb. Karena itu sangat berkaitan dengan citra perusahaan. Kadang sekretaris diminta untuk menemani atasan untuk melakukan presentasi menggantikan sang atasan. Karena itulah sekretaris harus bisa belajar berbicara di depan publik atau pada saat meeting. Seorang sekretaris profesional harus memiliki karakteristik dimana ia harus menjadi orang metodis, dengan mata yang bagus untuk hal detail, pengorganisasi yang baik, dengan pikiran yang tertib, membawa ke objektivitas ke proses, Segera berurusan dengan korespondensi.

Pada zaman era globalisasi, sekretaris harus mengembangkan diri mengikuti perkembangan Ilmu pengetahuan dan teknologi. Untuk menjadi sekretaris yang profesional harus dapat mengikuti perkembangan zaman sehingga mampu dapat mengatasi perubahan dan dapat bekerja semaksimal mungkin untuk menghadapi dunia kerja seorang sekretaris dengan daya saing yang semakin maju.

Adapun pengetahuan dan wawasan yang harus diketahui oleh seorang sekretaris adalah sebagai berikut :

a. Pengetahuan akan bidang usaha tempat kita bekerja

b. Pengetahuan akan produk dari perusahaan

c. Pengetahuan akan Rekanan bisnis pimpinan

d. Pengetahuan akan pesaing dari perusahaan

Ada banyak cara yang dapat diakukan untuk menambah wawasan dan pengetahuan diantaranya adalah :

a. Banyak membaca dan mengikuti perkembangan dari berita-berita surat kabar dan media elektronik

b. Banyak mengikuti forum, workshop, seminar, pelatihan, kursus, diskusi,

c. Dan juga belajar menuangkan isi pemikiran kita dalam bentuk tulisan

Disamping kecerdasan intelektual,seorang sekretaris juga perlu memperhatikan kecerdasan logika dalam emosi kita, diantaranya yaitu : 
a. Meningkatkan profesionalisme kerja dan lingkungan kerja yang nyaman

b. Mampu menggunakan emosi secara efektif untuk mencapai tujuan (pengendalian emosi)

c. Memahami emosi orang lain

Sekretaris bertugas mencarikan dan menyajikan informasi kepada pimpinanya. Untuk itu ia harus pandai menggali informasi dari berbagai sumber, lalu menginterpretasikan sehingga dapat me milih informasi yang di nilai bermanfaat untuk disajikan kepada pemimpin. Sekretaris profesional harus mampu berpikir untuk mengidentifikasi sebab dan akibat setiap kali menghadapi masalah dan dapat mencari solusinya dengan tepat. Sehingga pimpinan tidak perlu terus menerus menuntun dan membimbing sekretaris, namun cukup mendelegasikan setiap penugasan kepada sekretaris dan sekretaris yang bersangkutan mampu menyelesaikan tugasnya secara baik . Pimpinan cukup memberi instruksi kepada sekretaris secara garis besar dan memberi delegasi secukupnya, selanjutnya menjadi tanggung jawab sekretaris untuk menindak lanjuti, termasuk memecahkan masalah yang dihadapi dalam setiap menyelesaikan tugasnya.

Seorang sekretaris harus mempunyai kemampuan dalam mengembangkan skill Human Relations Penjabarannya adalah sebagai berikut :

1. Team Work: mampu bekerja sama dalam team Tidak boleh menganggap diri lebih hebat, meremehkan orang lain, menutup mata pada keberhasilan dan kelebihan orang lain.

2. Positif Thinking, Komponen yang positif pada first impression :

- Sebut nama lawan bicara Anda

- Sambut tamu di pintu ruang Anda

- Tersenyum ketika berjumpa dengan tamu

- Salam dan mengulurkan tangan

- Jangan bicara terlalu pelan / keras

- Tunjukkan keramahan kepada setiap orang

3. Good reminder, Dalam hal ini lebih tertuju kepada Schedule pimpinan, hari ulang tahun pimpinan, karyawan, dan juga rekan bisnis.

4. Discrete, Tidak mudah membicarakan masalah seseorang / perihal yang diketahui kepada orang lain yang tidak berkepentingan

5. Tactful, Bijaksana dan berhati-hati dalam memilih kata atau berkomentar saat berhubungan dengan pimpinan ataupun orang lain. 


\section{PENUTUP/SIMPULAN}

Peranan seorang sekretaris adalah sebagai assistant atau tangan kanan pimpinan, pemegang rahasia terbaik dalam perusahaan, sebagai beranda perusahaan, sebagai penghubung pimpinan dengan pihak luar, perawat atau pelindung bagi pimpinan, jadi sangat diperlukan seorang sekretaris yang professional. Kemampuan dan keterampilan teknis harus mutlak dimiliki oleh seorang sekretaris professional untuk segala bidang ilmu. Kemampuan berkomunikasi dan interaksi dengan pimpinan, pihak luar dan juga rekan bisnis merupakan peranan yang sangat penting bagi seorang sekretaris, dia juga harus mempunyai wawasan yang luas untuk dapat bersaing di dunia bisnis. Pada era globalisasi ini, para eksekutif memiliki mobilitas yang tinggi, yang tentu saja menyebabkan peran seorang sekretaris menjadi semakin penting.

Untuk menjadi seorang sekretaris yang profesional harus memiliki kemampuan dan keterampilan seperti :

1. Kemampuan dan keterampilan teknis yang harus dan mutlak dikuasai oleh seorang sekretaris seperti computer, bahasa inggris, shorthand dan filling

2. Kemampuan berkomunikasi dan berinteraksi, oleh karena tugas sekretaris adalah berhubungan dengan berbagai macam individu yang masing-masing berbeda latar belakang, berbeda status sosial, berbeda kepentingan, berbeda kedudukan, maka sekretaris dituntut mampu memahami pihak- pihak yang berhubungan dengannya

3. Keterampilan penggunaan mesin-mesin kantor (PABX, mesin printer, mesin fotocopy, scanner, mesin fax, dan lain sebagainya).

Selain hal terebut diatas sekretaris yang Profesional secara teknik harus menguasai pekerjaan dan memiliki kecerdasan emosi yang tinggi dalam:
a. Pengambilan keputusan
b. Kepemimpinan
c. Kepuasan pelanggan
d. Kerjasama dan saling percaya

Dalam Fungsinya sebagai sekretaris yang professional, sekretaris dituntut mampu bekerja mandiri, bekerja tanpa pengawasan, untuk itu harus memiliki komitmen pada tugas .Tugas 
dan tanggung jawab seorang sekretaris profesional tidak hanya terbatas pada kelancaran kerja administrasi perusahaan. Lebih dari itu, seorang sekretaris profesional harus mampu mengkoordinasikan kegiatan kerja atasannya. Dalam hal ini segala pekerjaan yang berhubungan dengan komunikasi dan hubungan dengan relasi para eksekutif merupakan kewajiban dari seorang sekretaris dan menuntut kemampuan yang memadai. Seorang sekretaris yang profesional sangat berperan dalam pencapaian sasaran perusahaan, sesuai dengan target yang telah dicanangkan. Untuk itu ia harus juga mengembangkan diri dalam kemampuan manajerial yang jauh lebih luas daripada keterampilan operasional 


\section{REFERENSI/KEPUSTAKAAN}

Barnes, Carolyn and Manning, Marilyn. 2003. Menjadi Sekretaris Profesional, Batam Centre: Bina rupa Aksara.

Daniels, Diane and Barron, Ann. 1995. Sekretaris Profesional Pengakuan dan Keberhasilan, Jakarta: Erlangga.

Ernawati, Ursula. 2004. Pedoman Lengkap Kesekretarisan, Yogyakarta: Graha Ilmu

Hendarto, M.G. Hartiti dan Tulusharyono, F.X. 2003. Menjadi Sekretaris Profesional, Jakarta: Lembaga Manajemen PPM dan Penerbit PPM.

La Rose, 2003. Top Secretary membangun kepribadian dan keterampilan menjadi sekretaris profesional, Jakarta : Erlangga.

Nuraeni, Nani. 2008. Panduan menjadi sekretaris profesional. Jakarta : Trans Media Pustaka

Saiman. 2002. Manajemen Sekretaris. Jakarta: Ghalia Indonesia.

Sedarmayanti.2005. Tugas dan Pengembangan Sekretaris. Bandung: CV. Mandar Maju.

Sutarto. 1997. Sekretaris dan Tata Warkat. Yogyakarta: Gadjah Mada University Press.

Triwidodo, Titiek dan Kristanto, Djoko.2004. Jakarta. Pengembangan Kepribadian Sekretaris Gramedia Widiasarana Indonesia. 